\title{
PRICE BASED NOMINAL ANCHOR AND THE EFFECTIVENESS OF INFLATION CONTROL IN NIGERIA
}

\author{
${ }^{1}$ Uduakobong S. Inam, Ph.D and ${ }^{2}$ Williams A. Oscar \\ ${ }^{1}$ Department of Economics, Faculty of Social Sciences ,University of Uyo, \\ P.M.B. 1017, Uyo, Akwa Ibom State, Nigeria \\ ${ }^{2}$ Central Bank of Nigeria, Abuja, Nigeria
}

DOI: 10.46609/IJSSER.2020.v05i08.001 URL: https://doi.org/10.46609/IJSSER.2020.v05i08.001

\begin{abstract}
This paper examines the effectiveness of price based monetary policy instruments on inflation in Nigeria. Specifically, it: examines the response of inflation to the innovations from price based monetary policy anchors; and measures the extent of decomposition of price variables to inflation rate in Nigeria. The study uses monthly series of commonly used monetary policy price variables: Monetary Policy Rate (MPR), Exchange Rate, Interest rate (lending rate), Treasury bill rate and Cash Reserve Ratio (CRR). The findings of the paper showed that among the price variables used by the policymakers, the exchange rate is the most effective and the least effective is the Monetary Policy Rate. In order of their effectiveness on inflation, the cash reserve ratio stands second to the exchange rate, followed by the Treasury bill rate, and interest rate (lending rate). The effectiveness of the exchange rate reflects the import-dependent nature of Nigerians on foreign-produced consumer and capital goods whose prices transmit into domestic prices in the economy.
\end{abstract}

Keywords: Inflation, Interest Rate, Exchange Rate, Monetary Policy, Nigeria.

JEL Classification: E40, E45, E49, E52.

\subsection{Introduction}

Maintaining Price stability has been a major mandate of monetary authorities. This is because it plays a crucial role not only in promoting a sound domestic macroeconomic system that could foster growth and development, but it also creates a good signal to potential domestic and foreign investors. Faced with these outcomes, Central Banks (Reserve Banks) are saddled with the 


\section{International Journal of Social Science and Economic Research}

ISSN: $2455-8834$

Volume:05, Issue:08 "August 2020"

responsibilities of developing and implementing sound monetary policies that will aim at stabilizing prices and sustaining the growth of the domestic economy. In doing this, it explores several policy options and variables which they consider to be effective in achieving the ultimate monetary policy target.

In recent times, the society is dominated by fiat units of account, the value of each of which depends solely upon the policies of the particular central bank with responsibility for it. This has brought both opportunities and challenges. At the same time, the responsibilities of the world's central banks are more complex under a fiat system than they were when the banks' tasks were simply to maintain convertibility of their respective national currencies into gold, and it was not immediately apparent how the banks' new freedom should best be used (Woodford, 2003).

The rise of unexpected global innovations has made it key for countries to continually explore causes and trends in the level of prices. This has given birth to many ideologies concerning the movement of prices and the questions surrounding the determinants of price fluctuations and to what degree the policy variables affect price stability in a country. To this cause, academics and policymakers have crafted several ways of managing inflation in a country and have developed theories and models peculiar to the unique economic situation prevailing in their country. However, having an idiosyncratic policy to manage economic innovations in countries seems not to be feasible hence, the introduction of heterodox monetary policies.

Monetary policies available to central banks are broadly classified to be either price-based or quantity-based. The price-based policy variables consist of the interest rates and exchange rate of a country while the quantity-based policy consists of the different classification of credit and money in an economy. Both instruments are at the disposal of the authorities and they have the liberty of independently adopting whichever one they consider effective in addressing the existing economic condition in a country. This has been a smooth sail for monetary authorities of developed economies. However, it seems not to be the case in the developing economies, especially when it has to do with price stability. According to Woodford (2003), since the 1980s the central banks of the major industrial nations have been largely successful at bringing inflation down to low and fairly stable levels. This seems not to have involved any permanent sacrifice of other objectives; for example, real GDP growth has been if anything higher on average, and certainly more stable, in the period since inflation has been stabilized in the U.S. Somewhat paradoxically, this period of improved macroeconomic stability has coincided with a reduction, in certain senses, in the ambition of central banks' efforts at macroeconomic stabilization.

Maintaining inflation at a low and fairly stable level has been a major challenge in the Nigerian economy. Despite the efforts of monetary authorities in suppressing the level of inflation to a low level, the outcome seems not to reflect the efforts put in. For instance, 2015 was the last period 


\section{International Journal of Social Science and Economic Research}

ISSN: $2455-8834$

Volume:05, Issue:08 "August 2020"

that Nigeria maintained a single-digit inflation rate $(9.55 \%)$. From February 2016 to date, inflation has been on a double-digit with a high level of fluctuations. During the period, the level of inflation fluctuated between $9.62 \%$ in January 2016 and 18.72\% in January 2017 which was the highest level attained during the period. This would have been traced to the $17 \%$ increase in currency in circulation from the previous year. During the period, the monetary policy committee noted that the structural factors driving the sustained pressure on consumer prices were mainly dominated by the high cost of energy, transport, and the rising price of imports. In response to this, the monetary authority decreased the loan to deposit ratio from $79.95 \%$ in 2016 to $78.33 \%$ in 2017. In 2019, the rate of inflation hovered between $11 \%$ and $12 \%$. The year commenced with an inflation rate of $11.37 \%$ which later reduced to $11.31 \%$ and $11.40 \%$ in February and March respectively. A substantial reduction in inflation was observed from May to September 2019. However, in October, it increased again until it surpassed the $12 \%$ benchmark in 2020 , recording a value of $12.13 \%$.

The occurrence of price instability coupled with a high level of inflation frustrates policy implementation and erodes its effectiveness. Furthermore, owing to the dynamic nature of the economy, finding out which of the monetary policy variables is inter temporally more effective in controlling price level is a major task for policy makers. In Nigeria, the Monetary Policy Rate (MPR) has been used as the anchor variable on which every other price variable within the use of the monetary authority rests upon. The outcome of the monetary policy committee meetings of the Central Bank of Nigeria in recent years has revealed the mix of policy variables in both conventional and unconventional ways in order to achieve the major aim of the monetary authorities which is price stability. Unfortunately, these efforts seem not to yield the expected results as the rate of inflation is still skydiving and worsening as the world is facing a global pandemic causing both demand and supply shocks. In achieving their ultimate target, policy makers mostly exploit the price-based monetary policy tools in recent times, but the big question is: which of the price-based monetary policy tools is the most effective? This is can only be determined empirically.

Thus, the major objective of this paper is to examine the effectiveness of price based monetary policy instruments on inflation in Nigeria. Specifically, this study seeks to examine the response of inflation to the innovations from price based monetary policy anchors; and measure the extent of decomposition of price variables to inflation rate in Nigeria. This paper reveals information that will aid policy makers in making key decisions in the process managing the macroeconomy. Furthermore, it will contain information that will guide businessmen and potential investors in their daily operations of observing the nature of the Nigerian economy in order to make sound investment decisions. In the main, it is going to contribute to the existing stock of knowledge in the literature. The rest of the study is structured in the following order: section two presents both 


\section{International Journal of Social Science and Economic Research}

ISSN: $2455-8834$

Volume:05, Issue:08 "August 2020"

the theoretical and the empirical literature review; section three contains the research method; section 4 presents the analysis and interpretation of results; while section five presents the summary, conclusion and recommendations.

\subsection{Literature Review}

\subsection{Theoretical Literature Review}

The management of price level in a country has been an area of interest for many economists. Sporadically, scholars have developed thesis and theories concerning the determinants, causes and effects of inflation in an economy. To this effect, on a broad basis, the monetarist and structuralist schools of thought have divergent views on the causes of inflation. Whereas the monetarists are of the view that "inflation is always and everywhere a monetary phenomenon", the structuralists believe that it is rather a structural phenomenon. The theoretical framework of this paper relies broadly on the ideas of the monetarists. In this light, the paper is structured on three main theories: the monetarist theory of inflation; the Taylor's rule; and the purchasing power parity theory.

Alvarez, Lucas and Weber (2001) engaged in the consensus concerning the conduct of monetary policy whose central element was the use of short-term interest rate to control the rate of inflation. They opined that this was quite a drift away from the initial focus of monetary policy and inflation on the growth rate of money stock which is associated in concurrence with the prevailing level of inflation and interest rates. Contrasting with recent observations under the quantity theory of money, rapid money growth is the defining characteristic of monetary ease, and it is associated with high interest rates as well as high inflation. Although evidence could be drawn from the United States during the postwar period where increase in monetary aggregates (M1 and M2) accounted significantly for a corresponding increase in inflation, the changes recorded were mainly observed to be in a long-term. To that effect, there is need to examine what happens in the short-term. Hence, the need to reinstate the constructive role of short-term interest rates as monetary policy instruments.

In recent times, many theoretical models have been designed to rationalize the use of interest rate as a policy tool to control inflation rates. Many of these are policies classified as "Taylor rules," rules that specify the interest rate set by the central bank as an increasing function of the inflation rate. Theories differ considerably in their specification of the economy to which the Taylor rule is assumed to apply. In an examination of the role of interest rates and open market operations in the control of inflation, there is need to consider the segmented nature of markets. The pattern of demand for liquid and semi liquid assets in the money and capital market is partly directly and indirectly related to the interest rates. The Taylor rule makes it possible to feature this in and also 


\section{International Journal of Social Science and Economic Research}

ISSN: $2455-8834$

Volume:05, Issue:08 "August 2020"

a possible extension in the model to include other variables that are used by an economy to control inflation.

Consider the version of the Taylor rule which primarily shows how interest rates are set according to the formula:

$r_{t}=\hat{P}+\bar{\pi}+\theta\left(\pi_{t}-\pi\right)$

Where $\theta>0$ means that if the current rate of inflation $\pi_{t}$ is to exceed the target rate $\bar{\pi}$, we raise this period's interest rate above the target level, $\hat{P}+\bar{\pi}$.

Since the inflationary experience of the 1970s, Central Banks and academics have tended to seek simple rules that promote transparency and credibility in monetary policy-making. The prominent works by Taylor $(1993,1999$ a) have shown that U.S. Monetary policy in the period when inflation was successfully stabilized can be described in terms of an interest feedback rule in the form:

$i_{t}=r_{L}+\pi^{*}+\emptyset \pi\left(\pi_{t}-\pi^{*}\right)+\emptyset y\left(y_{t}-y^{*}\right)$

Where, $i_{t}$ denotes the rate of interest set by the federal reserve represented by the $r_{L}$ is the longrun rate of real interest, $\pi_{t}-\pi^{*}$ is the inflation gap, and $y_{t}-y_{t}$ is the output gap. In Taylor (1993), the coefficient $\emptyset \pi$ was set to 1.5 and $\varnothing y$ to 0.5 : the target for annual inflation is $2 \%$. The value of the constant $r_{L}+\pi^{*}=$ the steady state nominal interest rate if inflation is on target. From the equation 2 , it could be deduced that inflation plays a very critical role in the setting of the interest rates by the Central Bank (reserve bank). It could however be induced that interest rates set by the monetary authorities are also supposed to have an effect on the level of inflation in such a way that if the interest rate is reduced (monetary easing) inflation is supposed to increase and vice versa. Thus, rewriting equation 2 to make inflation the subject would express the relationship having interest rate as a causal variable still maintaining the steady state nominal interest rate if inflation is on target constant. Thus, we would have as expressed:

$$
\pi_{t}=i_{t}-r_{\pi}+\pi^{*}+\emptyset y\left(y_{t}-y^{*}\right) \ldots .
$$

Equation 3 reveals that the steady state nominal interest rate $\left(\mathrm{r}_{\pi}\right)$ has a negative relationship with the level of inflation and that a positive output gap has a positive relationship with the rate of inflation.This behavior is mainly obtained in the real sector of the economy where goods and services are directly dealt with either for consumption or investment. Therefore, the interest rate here is treated as the cost of capital. Alternatively, it also pertinent to examine the behavior of interest rates as a reward for capital. This could be typically seen in the Fisher's theory where the activities of households in the bonds market would be examined. 


\section{International Journal of Social Science and Economic Research}

ISSN: $2455-8834$

Volume:05, Issue:08 "August 2020"

In the bond market, each household maximizes its lifetime utility over an infinite horizon. The household basically have a choice to either invest in bonds to earn interest and forego present consumption or spend income on consumer goods and forego future investment. Reinvesting funds would create $\left(\frac{1}{1+r_{t}^{n}}\right)$ yield for the consumer in the future. Therefore, one would expect a link between real rate and the nominal rate. Thus, we have:

$\frac{1}{1+r_{t}^{n}}=\beta E_{t} \frac{u \prime\left(C_{t+1}\right) P_{t}}{u \prime\left(C_{t+1}\right) P_{t-1}}$

Equation 4 simply expresses that the individual's choice between earning future yield based on interest rate and consumption based on the price level. This reveals that the monetary authorities could control inflation by raising the incentives for investment by increasing interest rate because a higher consumption could further increase price level. Equation 4 could be further reduced to the Fisher equation:

$\left(1+r_{t}^{n}\right)=\left(1+r_{t}\right)\left(\frac{P_{t+1}}{P}\right)$

Saving one additional dollar in period t yields $\frac{\left(1+r_{t}^{n}\right)}{P_{t+1}}$ units of the endowment good in period $t+1$. However, the price level next period, $P_{t+1}$, is unknown at time t. Inflation therefore makes the nominal discount bond a risky asset; the premium in effect alters the nominal rate to account for the additional risk. Therefore, in an economy where prices are high, interest rate is also increased to cushion the effect.

Another theory that forms part of the framework of this study is the Purchasing Power Parity (PPP) which was originated by Cassel (1918). The PPP consists of many alternative theories. Broadly, it is classified either in an absolute form or a relative form. The PPP is the macroeconomic counterpart to the microeconomic law of one price (LOOP) to express the PPP algebraically, we can compute the relative price of the two baskets of goods in each location.

$q_{D / F}=\frac{E_{D / F} * P_{F}}{P_{D}}$.

Where,

$q_{D / F}=$ relative price of basket of goods in foreign currency versus local currency.

$E_{D / F} * P_{F}=$ foreign price of basket of goods expressed in local currency.

$P_{D}=$ price of goods and services expressed in local currency. 
International Journal of Social Science and Economic Research

ISSN: 2455-8834

Volume:05, Issue:08 "August 2020"

There is no arbitrage when the basket of goods is the same price in both locations $q_{D / F}=1$. The Purchasing Power Parity holds when the price level in two or more countries is equal when expressed in a common currency. This is called the absolute PPP.

If the real exchange rate is below 1 then foreign goods are relatively cheap. In this case, the local currency is said to be strong, the foreign currency weak and it is undervalued. However, if the real exchange rate is above 1 , then foreign goods are relatively expensive. In this case, the dollar is said to be weak, the foreign currency is strong, and we say the foreign currency is overvalued. Equation 6 can be rearranged for the equality of price levels:

$E_{D / F}=P_{D} / P_{F}$

The purchasing power parity implies that the exchange rate at which 2 currencies trade should be the relative price levels of the 2 countries. Assuming that $E_{D / F}=\mathrm{E}$ and $\mathrm{P}=\pi$ equation 7 could be rewritten as:

$\frac{E_{t}-E_{t-1}}{E_{t-1}}=\frac{\pi_{D}-\pi_{F}}{1+\pi_{F}}$

Relative PPP claims that exchange rate movements should exactly offset any inflation differential between 2 countries RPPP:

$\frac{E_{t+1}}{E_{t}}=\frac{1+\pi_{D}}{1+\pi_{F}}$

We rewrite equation 9 as:

$\frac{E_{t+1}-E_{t}}{E_{t}}=\frac{\pi_{D}-\pi_{F}}{1+\pi_{F}}$

The exchange rate should offset inflation:

$E_{t+1}^{P P P}=E_{t} * \frac{1+\pi_{D}}{1+\pi_{F}} \ldots$

The exchange rate set by the monetary authorities should be such that can offset the inflation differential trading partners. This is an evidence on how exchange rate may be used to control inflation in order to avoid imported inflation.

\subsection{Empirical Literature Review}

Several empirical studies have been conducted on inflation and monetary policy in Nigeria and as such different scholars have developed findings as to how monetary policy is effective in 


\section{International Journal of Social Science and Economic Research}

ISSN: $2455-8834$

Volume:05, Issue:08 "August 2020"

controlling inflation in Nigeria. Ebiringa and Anyaogu (2014) modelled a long-run relationship between exchange rate, interest rate and inflation using autoregressive distributed lag (ARDL) co-integration analysis. The study used historical data on Nigeria (1971-2010) to establish a significant short-run and long-run positive relationship between inflation and exchange rate. The results showed that interest rate exhibited an insignificant negative relationship with inflation. The study recommended that there should be a concerted effort of all monetary authorities to ensure that periodic variation in inflation is kept at the barest minimum for stability in exchange rate regime to be achieved.

Fatukasi, B. (2004) investigated the determinants of inflation in Nigeria between 1981 and 2003 and revealed that all explanatory variables (fiscal deficits, money supply, interest and exchange rates) significantly and positively impacted on the rate of inflation in Nigeria during the period under review. The explanatory variables accounted for $72 \%$ of the variation in inflation during the period with the error terms capturing $28 \%$ of the variation. Furthermore, Awomuse and Alimi (2012) investigated the relationship between expected inflation and nominal interest rates in Nigeria and the extent to which the Fisher effect hypothesis holds, for the period 1970-2009. Using the Johansen Cointegration approach and Error Correction Mechanism, the findings reveal that causality run strictly from expected inflation to nominal interest rates as suggested by the Fisher hypothesis and there is no "reverse causation" and only about 16 percent of the disequilibrium between long-term and short-term interest rate is corrected within the year.

Chuku (2015) examined the effects of monetary policy shocks on output and prices in Nigeria using Structural Vector Autoregression (SVAR) model. The findings showed that monetary policy innovation carried out on quantity-based nominal anchor (M2) has modest effect on output and prices with a very fast speed of adjustment while shocks on price-based anchors (MRR and REER) have neutral and fleeting effects on output. In a recent study, Okotori (2019) evaluated the dynamics of monetary policy and inflation in Nigeria using monthly data from 2009-2017. The findings of the study showed that money supply, exchange rate, monetary policy rate, treasury bills rate, reserve requirement and liquidity ratio have significant and effective impact on the inflation rate.

Using autoregressive distributed lag analytical framework, Ezirim, Edith and Muoghalu (2012) examined the interdependencies between exchange rates and inflation rates behavior in Nigeria. they found that exchange rates movements and inflation spiral are cointegrated, associating both in the short run and in the long run. Thus, indicating that in a regime of inflation targeting, policy aimed at exchange rates manipulation becomes a proper monetary action, and vice versa.

Ogunmuyiwa (2020) examined empirically the impact of monetary and fiscal policy management on the problem of inflation in Nigeria. Using Monthly data spanning from January 


\section{International Journal of Social Science and Economic Research}

ISSN: $2455-8834$

Volume:05, Issue:08 "August 2020"

2010 to October 2016, the study employed an Autoregressive Distributed Lag (ARDL). The results showed that broad money supply (M2) and Capital Expenditure (CE) were significant and are positively related (short and long run) to inflation in Nigeria. Exchange rate was significant and positively related to inflation in the long run. The study also revealed that Nigerian inflationary situation is driven by monetary and fiscal policies in the long run. Narrow money has no significant impact on inflation problem both in the short and long run in Nigeria.

Gbadebo and Mohammed (2015) examined the effectiveness of monetary policy as an antiinflationary measure in Nigeria. The co-integration and error correction methods approach were employed on quarterly time series data spanning from 1980Q1 to 2012Q4. The estimated result for the period covered revealed that interest rate, exchange rate, money supply and oil-price were the major causes of inflation in Nigeria. The study recommended that Nigerian inflationary situation is driven more by monetary impulses. In the same vein, Adigwe et al. (2015) examined the impact of monetary policy on the Nigerian economy. The Ordinary Least Square was used to analyze annual data between 1980 and 2010. The result revealed that monetary policy represented by money supply exerts a positive impact on GDP growth but negative impact on the rate of inflation.

On the contrary, Ngerebo (2016) examined the effectiveness of monetary policy in controlling inflation in Nigeria. The study modeled inflation rate in Nigerian (dependent variable) as a function of monetary policy (independent variables) made up of monetary policy rate (MPR), treasury bill rate (TBR), savings rate (SR), prime lending rate (PLR), maximum lending rate (MLR), growth of narrow money supply (M1g), growth of broad money supply (M2g), net domestic credit (NDC), net credit to government (NCG) and credit to private sector (CPS). The results show that MPR, TBR, PLR, MLR, and NDC are not statistically significant in controlling inflation.

Adegboyega (2014) examined the effect of changes in interest rates on inflation (measured by consumer price index (CPI)) in Nigeria using both descriptive and econometric methods. Four sets of hypotheses were tested by examining the impact of four variables that is prime lending rate; minimum rediscount rate; money supply and treasury bills rate on inflation. The empirical results showed that changes in interest rates and increase in the level of money supply were associated with rise in inflationary pressures. The study revealed the need for relevant authority to correct increase in inflation rate through the application of appropriate interest rates. Specifically, in periods of inflationary pressures, the lending and minimum rediscount rates should be tightened. Furthermore, Adodo, Akindutire, and Ogunyemi (2018) examined the effectiveness of monetary policy and control of inflation in Nigeria. Using Johansen Cointegration and Error Correction Model (ECM) to evaluate the effect of money supply, interest rate and exchange rate on inflation rate in Nigeria, the findings revealed there is a long run 


\section{International Journal of Social Science and Economic Research}

ISSN: $2455-8834$

Volume:05, Issue:08 "August 2020"

equilibrium relationship among the variables, and both Money Supply and Interest Rate are statistically significant in explaining variation in Inflation Rate while Exchange Rate is insignificant.

Umoru and Eseme (2013) examined the relationship between inflationary expectations and the variations in interest rate in Nigeria using the Generalized Method of Moment (GMM) estimator. The results revealed that interest rate variation has a negative significant effect on expected inflation in Nigeria. Accordingly, it was recommended that the monetary authority, that is, the Central Bank of Nigeria ( $\mathrm{CBN}$ ) should persistently vary the prime lending rate in order to check inflation expectations in the country. Ujuju and Etale (2016) examined the role of monetary policy instruments in controlling inflation in Nigeria. The study adopted interest rate, minimum rediscount rate, liquidity ratio, and cash reserve ratio as proxy for monetary policy instruments. The study found that interest rate, minimum rediscount rate, liquidity ratio and cash reserve ratio had no significant influence on inflation.

Bhattacharya (2013) studied the determinants of inflation and the role of monetary policy in controlling inflation in Vietnam. The findings of the study revealed that exchange rate and bank lending had significant impact on inflation. He concluded that Vietnam experienced higher degree of inflation than other Asian countries as result of the fact that the state bank had been passive in responding to changes in inflation.

\subsection{Methodology}

This paper employs an exploratory method of investigation where data collected are being analyzed using econometrics tool. It adapts the methodology of Ebiringa and Anyaogu (2014). Macroeconomic monthly data used for this study are sourced from secondary sources such as the National Bureau of Statistics (NBS) Annual Abstracts and the Central bank of Nigeria Monthly reports covering the period 2015:M1 to 2020:M3.

\subsection{Model Specification}

The model employed in this paper is drawn from the economic postulations of the monetarist theory of inflation as disintegrated in this paper and expressed in the fisher's theory of interest rate; Taylor's rule and the Purchasing Power Parity (PPP). Equations 11 and 12 express the fundamental relationship between inflation and the price variables. Hence, the model of this study is formulated to also include other variables that are frequently used as policy variables by the Central Bank of Nigeria to control inflation. Thus, the model of this study is specified in its fundamental form:

$I N F=(I N T R, E X R, M R R, T B R, C R R)$ 
International Journal of Social Science and Economic Research

ISSN: 2455-8834

Volume:05, Issue:08 "August 2020"
$(-)$
$(-)$
$(-) \quad(-)$
$(-)$

The linear form of the equation 12 is specified as:

$$
I N F=\beta_{0}+\beta_{1} I N T R+\beta_{2} E X R+\beta_{3} M R R+\beta_{4} T B R+\beta_{5} C R R+\mu
$$

Where,

$\mathrm{INF}=$ Inflation rate $(\%$ change in $\mathrm{CPI})$

INTR $=$ Interest rate (Lending rate)

EXR $=$ Exchange rate (I\&E window rate)

MRR = Minimum Rediscount Rate (MRR/MPR)

$\mathrm{TBR}=$ Treasury Bill Rate $(\mathrm{TBR})$

$\mathrm{CRR}=$ Cash Reserve Ratio (CRR)

$\mu \quad=$ error term

The apriori expectation is that the interest rates and exchange rate are expected to have a negative relationship with inflation. An increase in interest rate is used as a contractionary policy to discourage borrowing, hence reducing the amount of money in circulation. An increase in treasury bills rate makes investment attractive and reduces the consumption which would have driven inflation. An increase in the cash reserve ratio is also used as a policy tool to decrease the amount of money in circulation through the commercial banks. When the exchange rate of domestic currency to foreign currency increases, the price of imports reduces and thus transmits into domestic prices.

\subsection{Analytical Technique}

This paper employs the structural Vector Autoregression statistical technique. Blanchard and Watson (1986) and Bernanke (1986) developed procedures called the Structural Vector Auto Regression (SVAR) approach, which combine the features of the traditional structural modelling with those of the VAR methodology. This is an improvement in that it takes advantage of economic theory in the estimation of the IRFs and FEVDs and permits the definition of an explicit economic structure, which can be incorporated into the interpretation of the estimated VAR model. The mathematical representation of the VAR model used in this study is:

$I N F_{t}=\beta_{1} I N F_{t-p}+\beta_{2} I N T R_{t-p}+\beta_{3} E X R_{t-p}+\beta_{1} M R R_{t-p}+\beta_{1} T B R_{t-p}+\beta_{1} C R R_{t-p} \ldots \ldots$ 
Equation 14 above shows that the level of current inflation in time $t$ depends on past values of inflation and the past values of interest rate, exchange rate, minimum rediscount rate, treasury bill rate and cash reserve ratio. The SVAR technique will be used to: estimate the model above and examine the relationship which exists between price anchor variables and inflation in Nigeria; measure the rate at which inflation responds to the shocks from the price variables; and also measure the extent of variance error decomposition in the model.

\subsection{Data Analysis and Interpretation of Results}

\subsection{Trend of Interest Rate and Inflation in Nigeria}

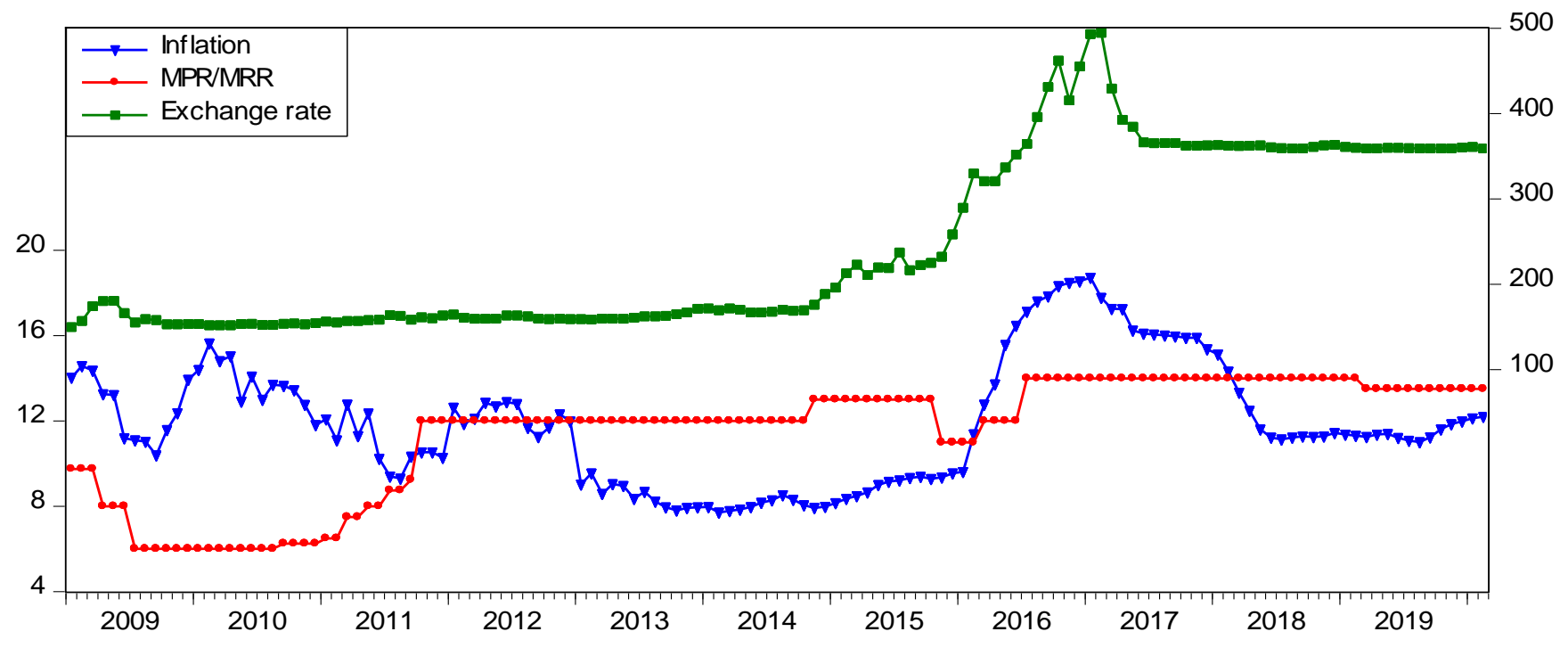

Figure 1: Trend of inflation, interest rate and exchange rate in Nigeria (Jan 09 - Feb 20)

Source: Author's Plot using data from Central bank of Nigeria database (2020)

Figure one (1) shows the trend of inflation, interest rate, exchange rate in Nigeria from January, 2009 to February, 2020. The trend reveals that there is some form of positive relationship between inflation and exchange rate. However, there seems to be a negative relationship between inflation and monetary policy rate. In 2009, as the inflation rate was rapidly decreasing from 14 percent to approximately 11 percent. In response to this, the Central Bank of Nigeria employed an expansionary policy by reducing interest rate from 9.75 percent to a record low of 6 percent. This could have been in a bid to stimulate economic activities as Nigeria was still going through a recovery phase from the 2006/2007 global financial crisis.

The effect of the easing was evident in the increase in the level of inflation from 10.4 percent in September 2009 to 15.64 percent in February, 2010. During this period, the exchange rate of naira to a dollar remained averagely stable at $\$ 155$ to $\$ 1$.In a bid to reduce the level of inflation 
which remained at a double digit, interest rate was increased and maintained at 12.00 percent from 2011 to 2014. In effect, there was a decline in the level of inflation from 12.00 percent recorded in March 2012 to 7.8 percent in April, 2014. Amidst this trend, there was a persistent depreciation of the Naira which was seen to have also contributed to inflation as Nigeria has always been known to be an import-dependent economy. As a way of managing the crashing value of naira which was hovering between $\$ 155$ per dollar in February, 2011 to $\$ 224$ in October, 2015, a high level of interest rate at 13.00 percent.

From 2016, monetary authority was faced with a twin adversity where they had to maintain the value of a rapidly depreciating naira and a skydiving trend of inflation. The economic situation in Nigeria worsened as inflation reached its peak at 18.71 percent in January,2017. In the succeeding month, the exchange rate also reached its peak at 494.70 per dollar. At this time, it was becoming more realistic that the monetary policy rate was becoming less effective in controlling inflation in Nigeria. Thus, the monetary authority had to explore other policy tools by way of practicing an unconventional monetary policy implementation. As a result, the inflation rate remained stable between 11.00 to 12.00 percent and exchange rate at $\$ 360$ as recorded in February, 2020.

\subsection{Data analysis}

\subsubsection{Lag Length Selection Criteria}

Table 1: Result of Lag Length Selection criteria

\begin{tabular}{lll}
\hline Variable & Lag Length & AIC \\
\hline Inflation & $(\mathrm{t}-15)$ & 2.010476 \\
MPR & $(\mathrm{t}-1)$ & 1.020563 \\
Ex rate & $(\mathrm{t}-11)$ & 7.881671 \\
INTR & $(\mathrm{t}-6)$ & 1.201165 \\
CRR & $(\mathrm{t}-5)$ & 3.717112 \\
TBR & $(\mathrm{t}-2)$ & 2.914630 \\
\hline
\end{tabular}

Source: Computed by Author using Eviews 
The lag length selection criteria test was carried out to determine the optimal lag length of each variable in the equation. The selection was mainly based on Akaike Information Criteria because its value was the least in the estimation output of the unrestricted Vector Auto Regression (VAR). The result of the lag length selection criteria shows that the optimal lag length for inflation is 15 months; monetary policy rate has an optimal lag length of 1 month; exchange rate has an optimal lag length of 11 months; interest rate has an optimal lag length of 6 years; cash reserve ratio has an optimal lag length of 5 years; treasury bill rate has an optimal lag length of 2 years. The estimation of the VAR model was done based on the optimal lags.

\subsubsection{Result of AR roots}

Inverse Roots of AR Characteristic Polynomial

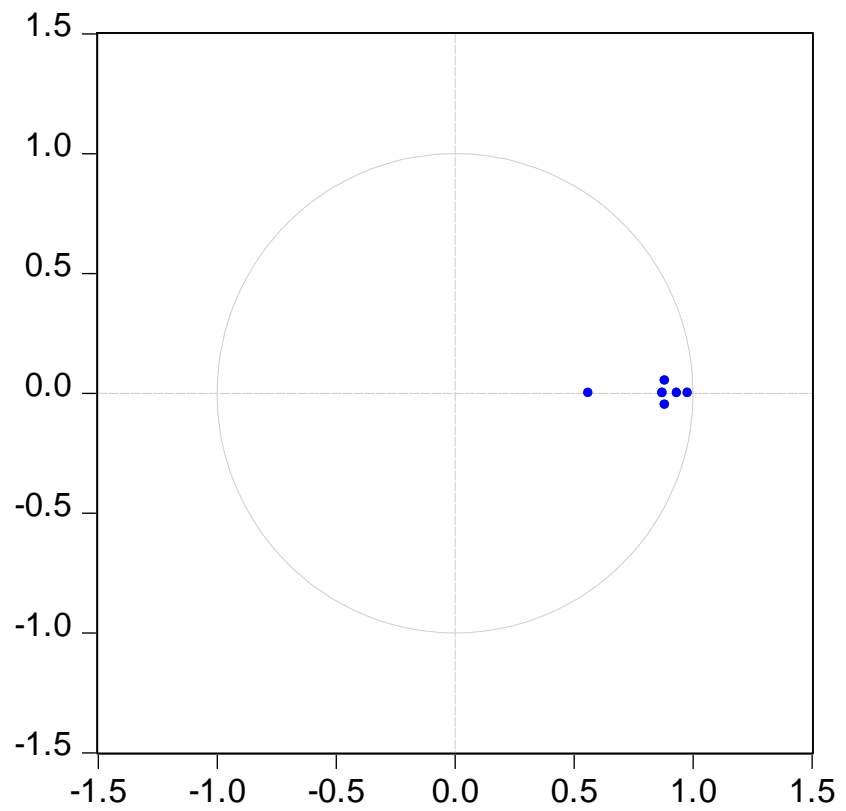

Figure 1: Inverse Roots of Characteristic Polynomial

Source: Computed by Author using Eviews

Figure 1 shows the result of the inverse roots. The graph basically reports the inverse roots of the characteristic AR polynomial. The estimated VAR system is stable (stationary) if all roots have modulus less than one and lie inside the unit circle. The stability of the VAR validates the result of the impulse response and standard errors. The graph shows that all the roots lie inside the unit circle. Therefore, the VAR system used in this study is stable and suitable for an impulse response estimation. 
International Journal of Social Science and Economic Research

ISSN: 2455-8834

Volume:05, Issue:08 "August 2020"

\subsubsection{Result of Impulse Response Functions}

Response to Structural VAR Innovations \pm 2 S.E.

Response of INFLATION to Shock1
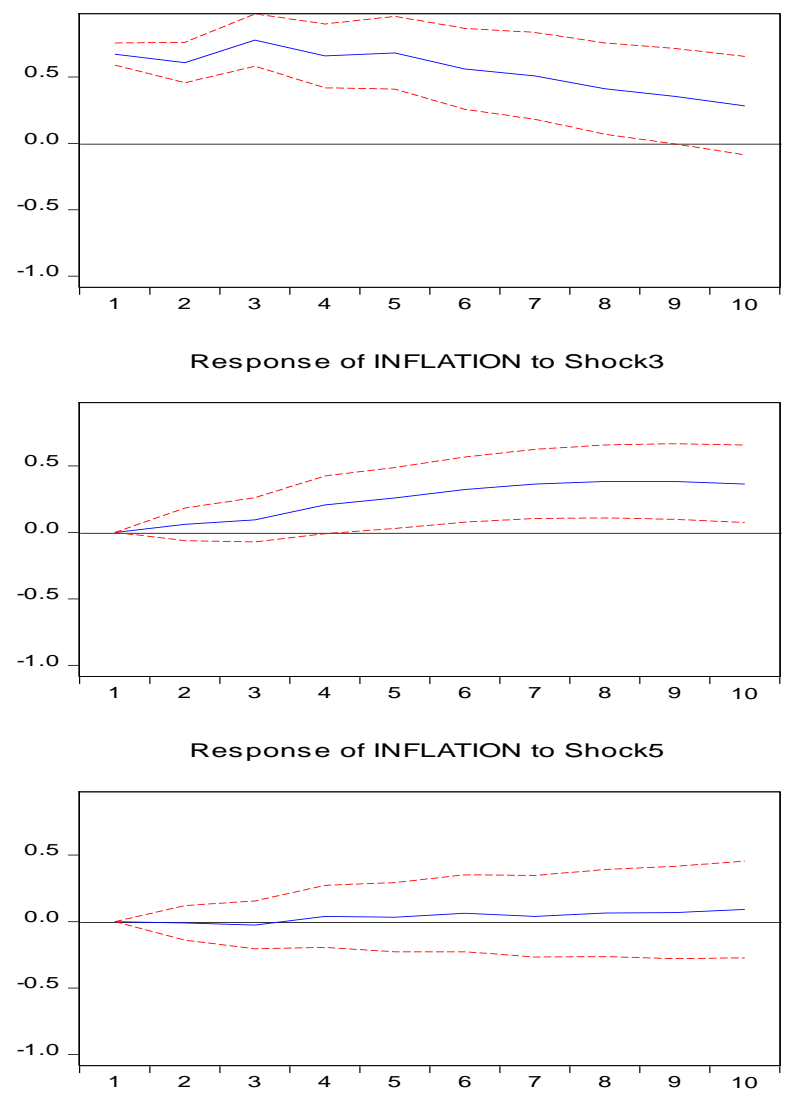

Response of INFLATION to Shock2
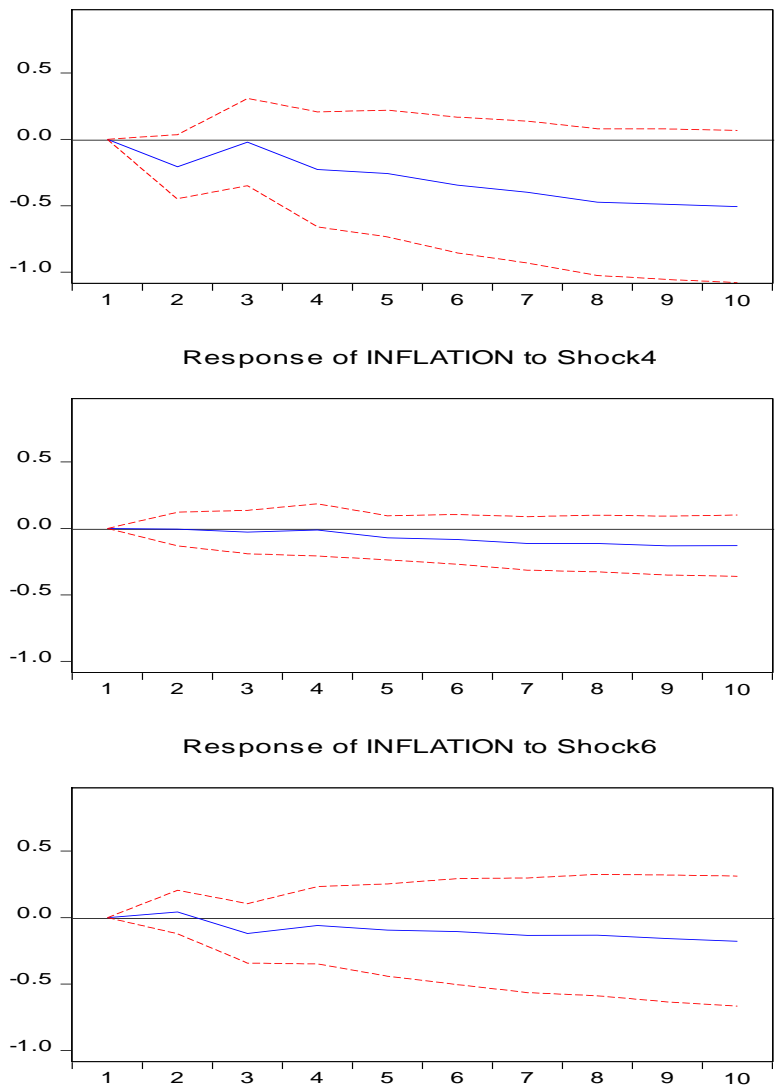

Figure 2: Result of Impulse Response analysis of inflation and Monetary policy.

Source: Computed by Author using Eviews

Figure 2 shows the result of the impulse response analysis. Impulse response analysis may be based on the counterfactual experiment of tracing the marginal effect of a shock to one variable through the system by setting one component of ut to one and all other components to zero and evaluating the responses of the yt's to such an impulse as time goes by. These impulse responses are just the elements of the Fi matrices. Because the ut's are the one-step ahead forecast errors of the system, the resulting functions are sometimes referred to as forecast error impulse responses (see, Lu"tkepohl, 2005). The result of the impulse response analysis shows that inflation responds the most to shocks from its lagged values which is usually the case. Furthermore, the result reveals that inflation also responds highly to the innovations from exchange rate followed by cash reserve ratio, treasury bill rate, INTR and then finally, MPR. 
International Journal of Social Science and Economic Research

ISSN: 2455-8834

Volume:05, Issue:08 "August 2020"

\subsubsection{Result of Variance Decomposition of Inflation and Monetary Policy}
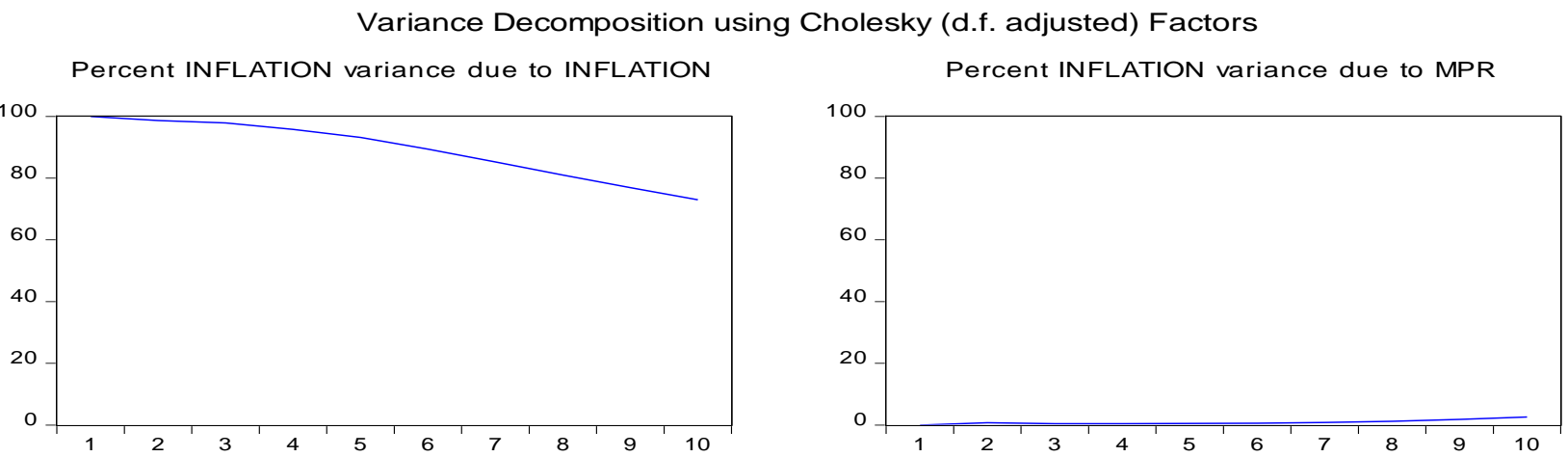

Percent INFLATION variance due to EX_RATE

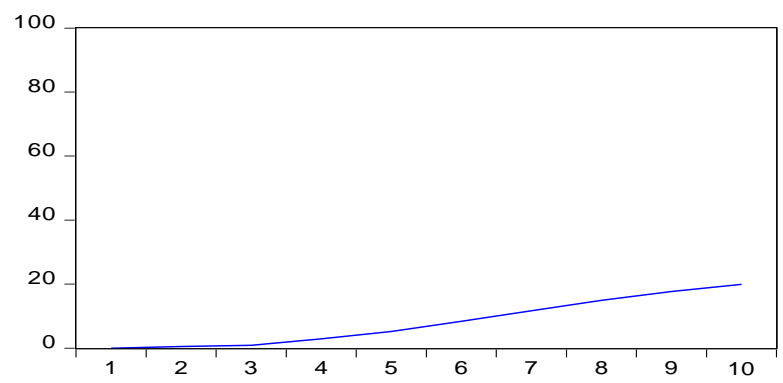

Percent INFLATION variance due to INTR

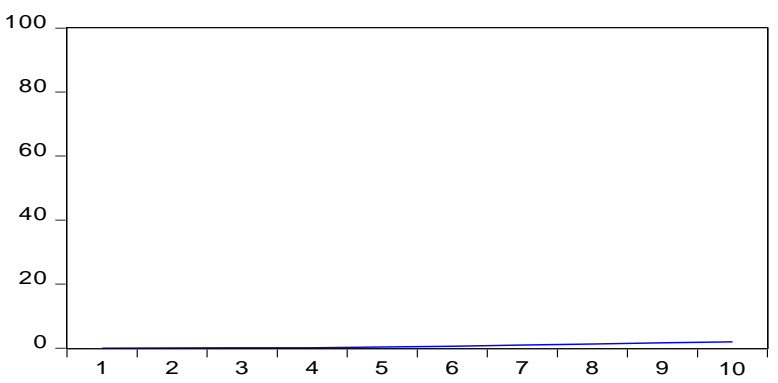

Percent INFLATION variance due to CRR
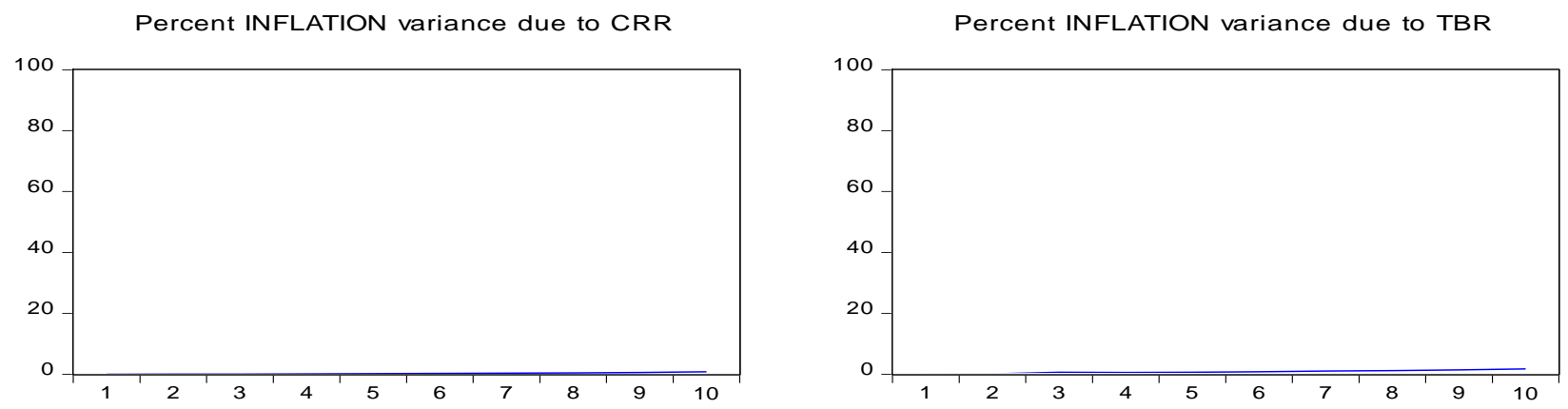

Figure 3: Result of Variance Decomposition of Inflation due to the monetary policy.

Source: Computed by Author using Eviews (2020)

Figure 3 shows the result of the variance decomposition of inflation due to changes in monetary policy. The result shows that averagely, the lagged values of inflation explain $98 \%$ of the variance in inflation; monetary policy rate explains $0.91 \%$ of the variance in inflation; exchange rate explains $8.2 \%$ of variance in inflation; interest rate (lending rate) explains $0.69 \%$ of variance in inflation; cash reserve ratio explains $0.28 \%$ of variance in inflation; treasury bill rate explains $0.83 \%$ of variance in inflation.

\subsection{Findings and Discussion}




\section{International Journal of Social Science and Economic Research}

ISSN: $2455-8834$

Volume:05, Issue:08 "August 2020"

The findings of the study show that the price-based monetary policy instruments are effective in controlling inflation in Nigeria, however, the degree of effectiveness varies. Based on the impulse response analysis, the study has shown that amongst the price variables, inflation responds the most to shocks from the exchange rate. Thus, the Nigerian economy is highly vulnerable to external shocks and inflation in Nigeria is seemingly imported.

As shown in the impulse response analysis, the findings further reveal that second to the exchange rate, the changes in the cash reserve ratio is highly effective in controlling inflation in Nigeria. This amplifies the importance of unconventional monetary policies as in recent times, the Central Bank of Nigeria employs such policies in managing the macro economy.

The Treasury bill rate also exerted a low degree of effectiveness in controlling inflation in Nigeria reflecting its nature as a purely commercial financial instrument where its subscription would be based on several other factors apart from its interest rate. It has been revealed that the TBR is not a viable policy instrument.

Based on the findings of this study, the Monetary Policy Rate which is the anchor rate of the Bank has shown some level of impotence in controlling inflation in Nigeria. This is revealed in the result of the impulse response analysis in this study which revealed that the response of inflation to the innovations from MPR has been negative. The findings of the study in its variance decomposition analysis further reflect the effectiveness of the exchange rate in managing inflation in Nigeria as it explains the highest variance in inflation in Nigeria. The explanatory capacity of the other price variables is very minimal.

The finding of this study corresponds with the findings of Ezirim, et al (2012) that exchange rates movements and inflation spiral are cointegrated, associating both in the short run and in the long run. Thus, indicating that in a regime of inflation targeting, a policy aimed at exchange rates manipulation becomes a proper monetary action, and vice versa.

\subsection{Policy Implications of the Findings}

This study reveals that inflation responds highly to the changes in exchange rate. This implies that currency depreciation could be highly inflationary in the economy. Nigeria being an importdependent economy, the management of inflation would be very difficult. Nevertheless, inflation in Nigeria could be put in check if the exchange rate is effectively managed making the domestic currency highly valuable.

The study has also revealed that following the exchange rate, cash reserve ratio (CRR) is also very effective in controlling inflation in Nigeria. This implies that an increase in the cash reserve ratio which decreases the level of money supply, will cause a decrease in the level of inflation. 


\section{International Journal of Social Science and Economic Research}

ISSN: $2455-8834$

Volume:05, Issue:08 "August 2020"

The CRR should however be employed cautiously as it could affect economic growth through the non-availability of credit in the economy.

The treasury bill rate also exerted a low degree of effectiveness in controlling inflation in Nigeria. This implies that adjustments in the treasury bill rate does not necessarily drive the changes in the level of inflation and instead of placing emphasis on its use, policy-makers could explore other policy instruments. Thus, it is recommended that for this instrument to be made effective in the management of inflation, there should be an increase in financial inclusion. This could be done by the policy-makers extending the coverage of financial services to remote areas.

It has also been revealed that the Monetary Policy Rate (MPR) which is the anchor rate of the Bank has shown some level of impotence in controlling inflation in Nigeria. This is revealed in the result of the impulse response analysis in this study which revealed that the response of inflation to the innovations from MPR has been negative. This implies that the changes in the MPR may not actually impact on the level of inflation in Nigeria. This has been identified by the policy-makers in Nigeria, as they have employed unconventional monetary policies to achieve their ultimate target.

The findings of the study in its variance decomposition analysis further reflect the effectiveness of the exchange rate in managing inflation in Nigeria as it explains the highest variance in inflation in Nigeria. The explanatory capacity of the other price variables is very minimal. Implying that monetary policy action that does not consider exchange rate as a key variable may not be effective in stabilizing price and reducing inflation. However, it is also important for the policy-makers to be heterogeneous in their approach to monetary policy implementation as economic management is a dynamic process.

\subsection{Conclusion and Recommendations}

This paper has shown the degree of effectiveness of price based-nominal anchors in controlling inflation in Nigeria. Specifically, the paper set out to examine the response of inflation to the innovations from price-based monetary policy anchors; and measure the extent of decomposition of price variables to inflation rate in Nigeria using monthly series of commonly used monetary policy price variables: Monetary Policy Rate (MPR), exchange rate, interest rate (lending rate), treasury bill rate and cash reserve ratio (CRR). The findings of the paper showed that among the price variables used by the policymakers, the exchange rate is the most effective and the least effective is the Monetary Policy Rate. In order of their effectiveness on inflation, the cash reserve ratio stands second to the exchange rate, followed by the treasury bill rate, and interest rate (lending rate). The effectiveness of the exchange rate reflects the import-dependent nature of Nigerians on foreign-produced consumer and capital goods whose prices transmit into domestic prices in the economy. This is very clear in the trend analysis carried out in this study which 


\section{International Journal of Social Science and Economic Research}

ISSN: $2455-8834$

Volume:05, Issue:08 "August 2020"

revealed that there is a seemingly direct relationship between inflation and the exchange rate in Nigeria.

No monetary policy instrument remains eternally effective, however, scenarios such as consumption, investment, expenditure, output, and trade patterns make effective a policy instrument. In the conclusion of this study, it has been revealed that price based monetary instruments are effective in controlling inflation in Nigeria. However, not all of them were periodically effective. Thus, the recommendations in this study are only short-term which portray the nature of unconventional policy implementation in Nigeria. For the observed period, the exchange rate seemed to be the most effective price-based monetary policy instrument while the monetary policy rate seemed to be ineffective. This may not be the case in another period.

Based on the degree of effectiveness of the price variables, this paper recommends that policies that aim at stabilizing the exchange rate and prevent it from increasing should be adopted. Specifically, the bank could temporarily intervene in the foreign exchange market until the manufacturing sector in Nigeria is vibrant and developed enough to produce goods with little or no external inputs in terms of labor or technology. By so doing, the cost of producing goods for exports will be very minimal thus domestic prices will also decrease. Besides, there is a need for the government to promote the use of made in Nigerian products as this will automatically discourage importation of goods that could be locally sourced. This will improve the country's balance of payments.

The cash reserve requirement is also a very effective monetary policy tool. It is therefore recommended that the government should intermittently increase the cash reserve ratio of the bank in periods of inflation. However, the use of this policy should be based on the immediate needs of the economy as this could translate to a credit crunch stalling economic output and increasing the cost of credit.

The Treasury bill rate is seen to be somewhat effective in controlling inflation in Nigeria through credit control. Thus, in a way of combating inflation, this paper recommends that policymakers should make the Treasury bill attractive to potential investors by increasing its rate. This will attract investment, thereby reducing the stock of money in circulation. However, this should be based on a proper assessment of the government's ability to create an absorptive net for the repayment of yields at maturity.

\section{REFERENCES}

Adegboyega, R. R. (2014). An Econometric Analysis of the Effects of Changes in Interest Rates on Inflation in Nigeria, International Journal of Economics, Commerce and Management, 2 (10): 1-24. 
International Journal of Social Science and Economic Research

ISSN: 2455-8834

Volume:05, Issue:08 "August 2020"

Adigwe, P.K., Echekoba, F.N. and Onyeagba, J.B.C. (2015). Monetary Policy and Economic Growth in Nigeria: A critical Evaluation. IOSR Journal of Business and Management 17(2): 110-119.

Adodo, F. L., Akindutire, O. R. and Ogunyemi, J. K. (2018). Monetary Policy and Inflation Control in Nigeria, International Journal of Management, IT and Engineering 8(12), 154-170.

Alvarez, F., Lucas, R. E. and Weber, W. E. (2001). Interest Rates and Inflation, American Economic Review, 91(2): 219-225.

Awomuse, B. O. \&Alimi, S. R.,(2012). The Relationship between Nominal Interest Rates and Inflation: New Evidence and Implication for Nigeria, MPRA Paper 49684, University Library of Munich, Germany.

Bhattacharya, R. (2013). Inflation Dynamics and Monetary Policy Transmission in Vietnam and Emerging Asia, IMF Working Paper No. WP/13/155, 1 - 21.

Bernanke, B.S. (1986). Alternative Explanations of the Money Income Correlation, Carnegie Rochester Conference Series on Public Policy, Elsevier, 25(1): 49-99.

Blanchard, O.J. and Watson, M. (1986). Are Business Cycles all alike? In Robert j. Gordon, ed., The American Business Cycle. Chicago: University of Chicago Press.

Cassel, G. (1918). Abnormal Deviations in International Exchanges, Economic Journal, 28: 413-415.

Chuku, A.C. (2015). Measuring the Effects of Monetary Policy Innovations in Nigeria: A Structural Vector Autoregression (SVAR) Approach, Journal of Accounting, Economics, Finance and Banking Research, 5(5): 112-129.

Ebiringa, O. T. and Anyaogu, N. B. (2014). Exchange Rate, Inflation and Interest Rate Relationships: An Autoregressive Distributed Lag Analysis, Journal of Economics and Development Studies, 2, 263-279.

Ezirim, C. B., Edith, A. A. and Muoghalu, M. I. (2012). Autoregressive Distributed Lag Analysis of Interdependencies Between Inflation and Exchange Rates in Sub-Saharan Nigeria. The IABPAD Conference Proceedings, Dallas, Texas, Vol. 9, No. 2, April 19-22, 2012, pp. 1082-1093. 


\section{International Journal of Social Science and Economic Research}

ISSN: $2455-8834$

Volume:05, Issue:08 "August 2020"

Fatukasi, B. (2004). Determinants of Inflation in Nigeria: An Empirical Analysis, International Journal of Humanities and Social Sciences, 1(18):262-271.

Gbadebo, A.D. and Mohammed, N. (2015). Monetary Policy and Inflation Control in Nigeria. Journal of Economics and Sustainable Development 6(8): 108-116.

Ngerebo, T. A. (2016). Monetary Policy and Inflation in Nigeria. International Journal of Finance and Accounting, 2016, 5(2): 67-76.

Okotori, T. W (2019). The Dynamics of Monetary Policy and Inflation in Nigeria. Journal of Economics and Finance (IOSR-JEF), 10(2): 37-49.

Ogunmuyiwa, M. S. (2020). Managing the Inflation Problem in Nigeria using the FiscoMonetary. Athens Journal of Business \& Economics, 6(3): 239-252

Taylor, J. B. (1993), Discretion Versus Policy Rules in Practice. Carnegie-Rochester Conference Series on Public Policy, Volume 39, December 1993, pps 195-214.

Taylor, J. B. (1999a), editor, An Historical Analysis of Monetary Policy Rules, chapter in J. Taylor (ed) National Bureau of Economic Research(NBER) book Monetary Policy Rules (1999)(p.319-348). Chicago: University of Chicago Press.

Ujuju, L. U. and Etale, L. M. (2016), Macroeconomic Analysis of The Relationship Between Monetary Policy Instruments and Inflation in Nigeria. International Journal of Business and Management Review, 4(6):31-39.

Umoru D. and Oseme, S. A. (2013). Inflation Expectations and Interest Rate Variation in Nigeria: An Econometric Assessment of the Evidence. International Journal of Development and Economic Sustainability, 1(2):1-12.

Woodford, M. D. (2003), Interest and Prices: Foundations of a Theory of Monetary Policy. Princeton,United Kingdom: Princeton University Press. 